\title{
Anti-desmoglein 3-mediated pathology of the human corneal epithelium in pemphigus vulgaris
}

\section{Patología del epitelio corneal humano en el pénfigo vulgar mediada por anti-desmogleína 3}

\author{
Jeffrey Jones ${ }^{\# 1}$, Ricardo F. Frausto ${ }^{\# 2}$, Shawna Langley ${ }^{1}$, Kelly S. Keefe ${ }^{1}$, Anthony J. Aldave ${ }^{2 *}$ and \\ John Affeldt ${ }^{1}$ \\ ${ }^{1}$ Loma Linda Eye Institute, Loma Linda University Medical Center, Loma Linda; ${ }^{2}$ Stein Eye Institute, David Geffen School of Medicine at UCLA, Los \\ Angeles. California, United States \\ "Contributed equally
}

\begin{abstract}
Purpose: To report novel corneal findings in an individual diagnosed with pemphigus vulgaris (PV), and to demonstrate a potential role for anti-desmoglein 3 (DSG3) autoantibodies in the pathology of the corneal epithelium. Methods: Cutaneous and slit-lamp biomicroscopic examinations were performed on a 37-year-old African American woman. To identify anti-DSG autoantibodies an oral mucosal lesion biopsy and a serum sample were used in several immunoassays. DSG transcripts in normal donor cornea, and DSG proteins in both donor and PV corneas, were measured using qPCR and fluorescence-immunohistochemitry (F-IHC), respectively. F-IHC was also performed to determine the presence of IgG1 and IgG4 in both donor and PV corneas. Results: Clinical examination revealed oral mucosal erosions and active, chronic ocular surface inflammation with significant superficial corneal scarring in both eyes. Anti-DSG3 autoantibodies were detected in the serum using an enzyme-linked immunosorbent assay. Direct immunofluorescence of oral mucosal lesion biopsy revealed intraepidermal linear/granular immunoglobin G deposits, consistent with PV. Indirect immunofluorescence of the patient's serum was negative, ruling out paraneoplastic pemphigus. All four DSG proteins were detected in normal donor cornea, while DSG3 showed a marked reduction in PV cornea. IgG4 was detected at the corneal epithelial cell-cell junctions in the PV cornea, which coincides with the observed reduction of DSG3. Conclusions: Although PV primarily involves the skin and oral mucosa, the corneal epithelium may also be affected. In the absence of any identifiable secondary cause, corneal pathology associated with PV is most likely mediated by IgG4 autoantibodies directed against DSG3 in the corneal epithelium.
\end{abstract}

Key words: Pemphigus vulgaris. Desmogleins. Corneal epithelium. Autoimmunity

\section{Resumen}

Objetivo: Informar nuevos hallazgos corneales en un individuo diagnosticado con pénfigo vulgar (PV) y demostrar un posible papel de los autoanticuerpos anti-desmogleína 3 (DSG3) en la patología del epitelio corneal. Métodos: Se

\section{Correspondence:}

*Anthony J. Aldave

Stein Eye Institute,

100 Stein Plaza, UCLA, Los Angeles, Date of reception: 10-12-2018

CA 90095-7003, United States Date of acceptance: 11-03-2019

Email: aldave@jsei.ucla.edu

DOI: 10.24875/RMOE.M19000071
Available online: XX-XX-2019 Rev Mex Oftalmol(Eng).2019;93(4):135-143

www.rmo.com.mx 2604-1731/@ 2019 Sociedad Mexicana de Oftalmología. Published by Permanyer México SA de CV. This is an Open Access article under the CC BY-NC-ND license (http://creativecommons.org/licenses/by-nc-nd/4.0/). 
realizaron exámenes cutáneos y de biomicroscopia con lámpara de hendidura a una mujer afroamericana de 37 años. Para identificar autoanticuerpos anti-DSG, se utilizó una biopsia de una lesión de la mucosa oral y una muestra de suero en varios inmunoensayos. Se midieron los transcritos de DSG en córnea de donante normal, y las proteínas de DSG en córneas tanto de donante como de PV, utilizando qPCR e inmunohistoquímica con fluorescencia $(F-I H C)$, respectivamente. También se realizó F-IHC para determinar la presencia de IgG1 e IgG4 en córneas tanto de donante como de PV. Resultados: El examen clínico reveló erosiones de la mucosa oral e inflamación crónica activa de la superficie ocular con cicatrización corneal superficial significativa en ambos ojos. Se detectaron autoanticuerpos anti-DSG3 en el suero utilizando un ensayo inmunoabsorbente ligado a enzimas. La inmunofluorescencia directa de la biopsia de la lesión de la mucosa oral reveló depósitos intraepidérmicos de inmunoglobulina G lineales/granulares, compatibles con PV. La inmunofluorescencia indirecta del suero del paciente fue negativa, descartando pénfigo paraneoplásico. Se detectaron las cuatro proteínas de DSG en la córnea de un donante normal, mientras que la DSG3 mostró una reducción marcada en la córnea con PV. Se detectó IgG4 en las uniones célula-célula del epitelio corneal en la córnea con PV, lo que coincide con la reducción observada de DSG3. Conclusiones: Aunque el PV afecta principalmente la piel y la mucosa oral, el epitelio corneal también puede verse afectado. En ausencia de cualquier causa secundaria identificable, la patología corneal asociada con PV probablemente está mediada por autoanticuerpos IgG4 dirigidos contra DSG3 en el epitelio corneal.

Palabras clave: Pénfigo vulgar. Desmogleínas. Epitelio corneal. Autoinmunidad.

\section{Introduction}

Pemphigus is a rare bullous dermatologic disease characterized by flaccid cutaneous blisters and/or ulcerations of mucosal membranes caused by an autoimmune reaction directed against the desmoglein family of proteins, which are present in the desmosomes of epithelial cellular junctions ${ }^{1,2}$. The three main types of pemphigus include pemphigus vulgaris (PV), pemphigus foliaceus (PF) and paraneoplastic pemphigus (PNP). Each pemphigus subtype has a unique clinical presentation that correlates to its specific autoantibody profile. Pemphigus vulgaris is by far the most common subtype of pemphigus and is caused by autoantibodies to desmoglein 1 (DSG1) and desmoglein 3 (DSG3)2. The majority of individuals with PV demonstrate both mucosal and cutaneous involvement, but isolated mucosal disease can be seen. Pemphigus foliaceus has a more mild disease course than PV, with blisters limited to the skin, and is associated with autoantibodies to only DSG1 ${ }^{3,4}$. Paraneoplastic pemphigus typically presents with variable cutaneous findings, severe mucosal involvement and an associated internal malignancy, most commonly non-Hodgkins lymphoma. The autoantibodies of PNP bind to DSG1, DSG3 and the hemidesmosomal proteins of the dermoepidermal junction ${ }^{5,6}$. PNP can be distinguished from PV via direct and indirect immunofluoresence, which show antibodies located in both the epidermal desmosomes and hemidesmosomes of the dermoepidermal junction ${ }^{5}$.

Ocular involvement is an uncommon manifestation of $\mathrm{PV}$, reported in only $7-26 \%$ of cases $2,7,8$. When manifest, the most common ocular finding is a noncicatricial bilateral conjunctivitis $2,7,-11$. Corneal involvement has been reported as exceedingly rare, with only 3 cases identified in the peer-reviewed literature prior to 2014 $12-14$. In 2014, Chirinos-Saldana and colleagues published a series of $15 \mathrm{PV}$ cases demonstrating corneal changes ${ }^{15}$. It should be noted however, that this group was unusual in that only two patients had any extra-ocular manifestations of PV and many had confounding systemic conditions or received medications potentially associated with corneal changes ${ }^{15}$. Additionally, none of the previous reports of ocular involvement in PV confirmed the direct involvement of the cornea through attempting to identify either DSG1 or DSG3 in the corneal epithelium or the presence of corneal autoantibodies to these desmogleins ${ }^{12-15}$. Therefore, we report primarily corneal involvement in PV, confirmed via the demonstration of an apparent colocalization of DSG3 and immunoglobulin G4 in the corneal epithelium of an affected individual.

\section{Purpose}

We report novel corneal findings in an individual diagnosed with PV and describe a potential role for anti-desmoglein 3 (DSG3) autoantibodies in the PV-associated pathology of the corneal epithelium. These findings may provide a pathophysiologic mechanism for the distinctive clinical presentation manifest in this case. In addition, we report the gene and protein expression of the desmogleins (DSG1-4) in the corneal epithelium. 
Table 1. Primers used in quantitative polymerase chain reaction

\begin{tabular}{|l|l|l|l|}
\hline Gene & Primer Bank ID & Forward $\left(5^{\prime}-3^{\prime}\right)$ & Reverse $\left(5^{\prime}-3^{\prime}\right)$ \\
\hline DSG1 & $119703743 c 2$ & AACCCAATCGCCAAAATTCACT & ACCTCTCGATCAACTATGGATGT \\
\hline DSG2 & $189181754 c 2$ & TTGTTGGGTCTGTTGAAGAGTTG & TTCAGGGTATTGGGCTCATCT \\
\hline DSG3 & $119964717 c 1$ & GCAAAAACGTGAATGGGTGAAA & TCCAGAGATTCGGTAGGTGATT \\
\hline DSG4 & $197313786 c 1$ & CAGCCTGTCGAGAAGGAGAG & CCCTACTCCAGAAATCCGGTAT \\
\hline GAPDH & N/A & CGACCACTTTGTCAAGCTCA & AGGGGTCTACATGGCAACTG
\end{tabular}

\section{Methods}

The tenets of the Declaration of Helsinki were adhered to in the treatment of the individual reported in this study. Study approval was obtained from the Univeristy of California, Los Angeles (UCLA IRB \#11-000020).

\section{Clinical examination}

A 35-year-old African American woman presented to the dermatology clinic at Riverside County Regional Medical Center (RCRMC). A standard cutaneous examination was performed by one of the authors (S.L.). The patient was subsequently referred to the Loma Linda University Eye Clinic where two of the authors (J.J. and J.A) performed a slit-lamp biomicroscopic examination.

\section{Diagnostic laboratory tests}

After informed consent was obtained, a peripheral blood sample and a mucosal lesion biopsy were collected. Serum was isolated from the plasma and submitted to the RCRMC Diagnostic Laboratory where an enzyme-linked immunosorbent assay (ELISA) was performed for detection of anti-DSG3 autoantibodies. To rule out paraneoplastic pemphigus, serum was also subjected to indirect immunofluorescence (IIF) using rat bladder epithelium as a substrate ${ }^{6}$. Direct immunofluorescence (DIF) using antibodies against immunoglobulin isotypes was also performed on the oral mucosal biopsy specimen.

\section{Histopathology}

Following the performance of a penetrating keratoplasty on the patient, the corneal button was fixed in $10 \%$ buffered formalin and submitted to the Loma Linda University Medical Center Pathology Laboratory for processing. The tissue was subsequently paraffin-embedded, sectioned and stained with hematoxylin and eosin using a standard histology staining protocol.

\section{Total RNA isolation and complementary DNA synthesis}

Fourteen corneas from nine donors were obtained from eye banks associated with the Vision Share consortium of eye banks. Corneal epithelium was enzymatically (Dispase II, Roche, Basel, Switzerland) dissociated and the Descement membrane stripped from donor eye bank corneas with confirmed unremarkable ocular history. Corneas denuded of epithelium and endothelium were processed for stromal fibroblasts. The three corneal layers were homogenized in TriReagent (Life Technologies, Carlsbad, CA), which is a phenol/ guanidine thiocyanate containing solution, and total RNA was isolated per the manufacturer's instructions. Briefly, after tissue homogenization in TriReagent, phase separation was accomplished by addition of chloroform and centrifugation. The top aqueous phase containing RNA was separated from the lower organic phase containing proteins and DNA, and RNA was subsequently precipitated and purified using alcohols. Preparation of poly $(A)^{+}$complementary DNA from 100ng of total RNA was performed using oligo(dT) $)_{20}$ primers and the SuperScript ${ }^{\circledR}$ III First Strand Synthesis System (Life Technologies, Carlsbad, CA) per the manufacturer's instructions.

\section{Quantitative polymerase chain reaction (PCR)}

To determine the transcript levels of the desmogleins 1-4 in the three main cell types (epithelial, fibroblasts and endothelial) of the cornea, quantitative PCR was performed using transcript-specific oligonucleotides whose sequences were obtained from the Harvard 
Rev Mex Oftalmol (Eng). 2019;93

Table 2. Antibodies used in immunohistochemistry

\begin{tabular}{|c|c|c|c|c|c|c|}
\hline Target Protein & Isotype & Immunogen Species & Clonality & Dilution & Vendor & $\begin{array}{l}\text { Catalog } \\
\text { Number }\end{array}$ \\
\hline \multicolumn{7}{|c|}{ Primary Antibodies } \\
\hline DSG1 & mouse IgG & human & monoclonal & 1:200 & Millipore & MABT118 \\
\hline DSG2 & mouse $\lg G_{1}$ & human & monoclonal & $1: 100$ & Life Technologies & $32-6100$ \\
\hline DSG3 & goat IgG & human & polyclonal & $1: 100$ & R\&D Systems & AF1720 \\
\hline DSG4 & goat IgG & human & polyclonal & $1: 33$ & Santa Cruz Biotechnology & sc-28067 \\
\hline KRT12 & rabbit IgG & human & polyclonal & $1: 33$ & Santa Cruz Biotechnology & sc-25722 \\
\hline $\lg \mathrm{G} 1$ & mouse $\lg _{2 a k}$ & human & monoclonal & 1:200 & Thermo Scientific & MH1013 \\
\hline $\lg G 4$ & mouse $\operatorname{lgG}_{3}$ & human & monoclonal & 1:100 & Thermo Scientific & MA5-16716 \\
\hline \multicolumn{7}{|c|}{ Secondary Fluorescence Conjugated Antibodies } \\
\hline$R b-\lg G$ & donkey IgG (A488) & rabbit & polyclonal & $1: 500$ & Life Technologies & A-21206 \\
\hline Ms-IgG & donkey IgG (A594) & mouse & polyclonal & $1: 500$ & Life Technologies & A-21203 \\
\hline Gt-IgG & donkey IgG (A594) & goat & polyclonal & $1: 500$ & Life Technologies & A-21207 \\
\hline
\end{tabular}

Primer Bank database (Table 1); http://pga.mgh.harvard.edu/primerbank/index.html) ${ }^{16-18}$. Quantitative PCR was performed using 2x KAPA SYBR FAST qPCR Master Mix (KAPA Biosystems, Boston, MA) in a $10 \mathrm{uL}$ reaction volume placed in a 384 well microplate. Reactions were processed in the LightCycler 480 Real-Time System (Roche, Basel, Switzerland). Reaction conditions and data analysis were as previously described ${ }^{19}$. Relative expression was calculated using the mRNA levels of the housekeeping gene GAPDH and calculated using the comparative $C_{T}\left(2^{-\Delta \Delta C}\right)$ method. Relative expression levels were plotted as $2^{-\Delta C}{ }_{T}$ values. All qPCR experiments were performed on four independent biological replicates $(n=4)$.

\section{Fluorescence-immunohistochemical detection of DSGs}

Immunodetection was performed using antibodies (Table 2) targeting the four DSGs, IgG1, IgG4 and KRT12 (corneal epithelial biomarker) using a standard immunohistochemistry protocol. Briefly, sections of formalin fixed, paraffin embedded control and patient specimens were deparaffinized and rehydrated in an alcohol series followed by enzymatic (Proteinase $\mathrm{K}$, Sigma Aldrich, St. Louis, MO) antigen retrieval. Subsequently the sections were blocked in PBS $+0.5 \%$ Tween-20 supplemented with $1 \%$ BSA and $10 \%$ horse serum, then incubated overnight with primary antibody diluted to $5 \mathrm{ug} / \mathrm{mL}$ in $125 \mathrm{uL}$ blocking buffer, washed $3 \mathrm{x}$ in PBS $+0.5 \%$ Tween-20 and followed by incubation with a fluorescence conjugated secondary antibody (Table 2) diluted 1:500 in blocking buffer, washed $3 x$ in PBS $+0.5 \%$ Tween-20 followed by $1 \mathrm{x}$ in PBS and mounted with Vectashield aqueous mounting medium (Vector Laboratories, Inc., Burlingame, CA) containing 40, 6-diamidino-2-phenylindole (DAPI). Fluorescence images were acquired by confocal microscopy.

\section{Statistical analysis}

The two-tailed unpaired t-test was utilized for identifying a significant difference in the means of the relative expression levels of DSG1-4 mRNA in epithelium compared with the level present in the stroma and endothelium. Differences in the means of gene expression between corneal stroma and corneal endothelium were considered significant with a $p \leq 0.05$.

\section{RESULTS}

\section{Clincal description}

A 35-year-old African American woman presented to the Riverside County Regional Medical Center (RCRMC) general eye clinic in 2010 complaining of lifelong, bilateral, variably red and painful eyes associated with blured vision. 


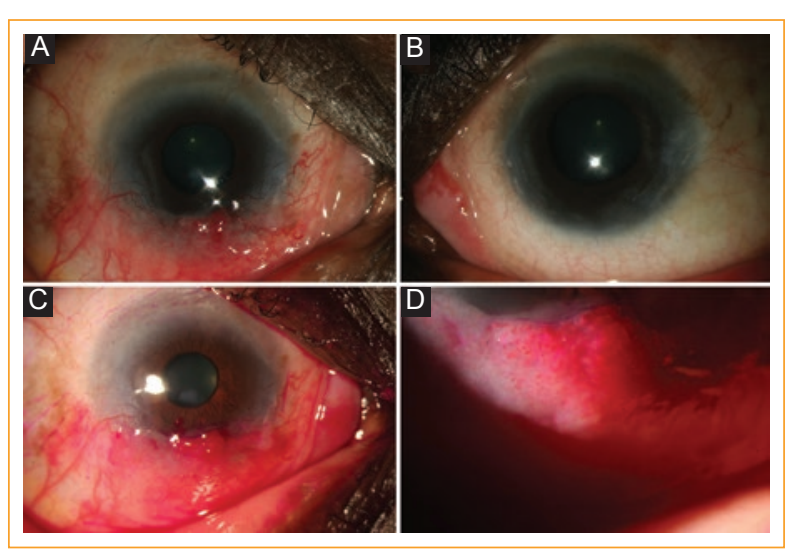

Figure 1. Peripheral corneal changes in individual with pemphigus vulgaris. A. Inferior pannus formation and 360 degree peripheral corneal opacification were observed in the right eye. B. Peripheral corneal opacification without significant pannus formation was seen in the left eye. C. Following staining with Rose Bengal, the borders of inflammatory pannus in the right eye were clearly visualized. D. Higher magnification view of the inferior limbal region in the right eye demonstrated thickening and prominent vascularity of the inflammatory pannus.

She was diagnosed with allergic conjunctivitis and successfully (if temporarily) treated with topical steroids. She developed a diffuse bullous dermatitis involving both her skin and oral mucosa, and was diagnosed with PV, which was later confirmed by the presence of immunoglobulin deposits in the oral mucosa and anti-DSG3 autoantibodies in the serum. In addition, IIF of serum was negative and PNP was excluded. Oral administration of prednisone and azathioprine cleared the bullous lesions. Subsequently, she experienced variable but persistent conjunctival injection and periodic recurrences of the oral mucosal erosions. She ultimately suffered an acute exacerbation of ocular inflammation and vision loss, which proved unresponsive to increased systemic immunosuppression. At this time, she was referred to the cornea clinic at RCRMC where she was evaluated by one of the authors $(\mathrm{JA})$.

On presentation, uncorrected visual acuity was count fingers at nine feet in the right eye and $20 / 100$ in the left eye, improving with pinhole to $20 / 70$ in each eye. Slit lamp examination revealed $3+$ bilateral conjunctival injection without evidence of erosions or symblepharon formation (Figure 1). The corneas of both eyes demonstrated 360 degree peripheral scarring and pannus formation extending $\sim 2-3 \mathrm{~mm}$ centrally (Figure $1 \mathrm{~A}$ and $1 \mathrm{~B}$ ). In the right eye, a paracentral $\sim 2 \mathrm{~mm} \times 3 \mathrm{~mm}$ epithelial defect was identified (previous photos taken after epithelial defect resolved). The right cornea also

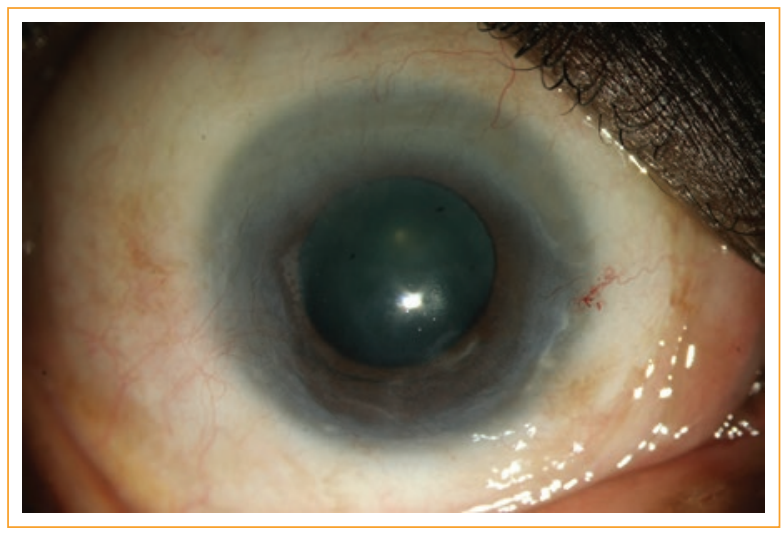

Figure 2. Two months after initiating topical steroid treatment, the right eye of the individual with PV shown in Figure 1 demonstrated resolution of the inflammatory pannus but persistent anterior corneal scarring.

demonstrated a discrete, inferior, elevated, scalloped, margined, gelatinous appearing lesion with corkscrew vessels, which appeared to overlie the peripheral scar tissue (Figures 1A, 1C, and 1D). A biopsy ruled out corneal extension of conjunctival intraepithelial neoplasia and a topical steroid was initiated in both eyes. Complete resolution was achieved in the right eye, with control of inflammation in both eyes (Figure 2).

Videokeratography revealed significant irregular astigmatism of each cornea, assumed to be induced by the superficial peripheral corneal scarring. Therefore, a superficial keratectomy was performed in the right eye. Five days following the procedure, corneal stromal necrosis developed that progressed to a large central Descemetocele, which subsequently perforated. Of note, the patient revealed that she had been using topical llevro (nepafenac $0.3 \%$ suspension) up to five times daily from the time of the corneal scraping to the follow up visit 5 days later, which likely contributed to the stromal necrosis. Given the inability to maintain closure of the perforation over a 15 week period despite serial (5) applications of cyanoacrylate glue, and with control of both ocular and dermatologic manifestations of PV on topical steroids and systemic immunosuppression, an $8 \mathrm{~mm}$ diameter penetrating keratoplasty was performed. Six months following surgery the uncorrected vision measured 20/150, and no evidence of recurrent stromal necrosis was observed.

\section{Histopathologic analysis of excised corneal specimen}

Histopathologic examination of the excised cornea demonstrated anterior corneal ulceration, chronic 


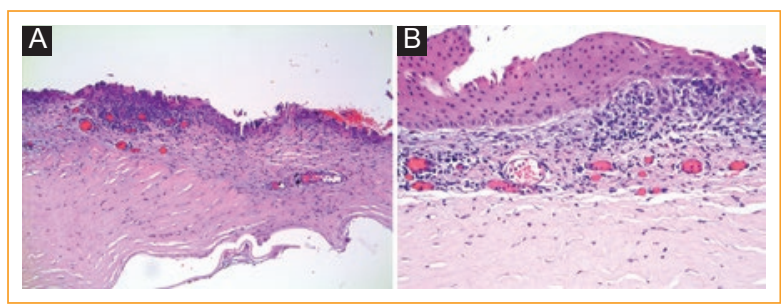

Figure 3. Histopathologic examination of corneal specimen from individual with PV revealed anterior corneal ulceration with chronic inflammatory cellular infiltrate, marked stromal thinning and vascularization, and a thin retrocorneal fibrous membrane beneath Descemet membrane (hematoxylin and eosin stain; magnification $x$ 10) (A). Higher magnification view demonstrated anterior stromal vessels and infiltration of chronic inflammatory cells (magnification x 20)(B).

stromal inflammation, stromal vascularization and retrocorneal fibrous tissue with endothelial cell atrophy (Figure 3).

\section{Expression of DSG genes in the cornea}

Expression of the DSG genes in the three predominant cell types that comprise the cornea were determined by qPCR (Figure 4). All four DSGs were expressed in the corneal epithelium, with statistically significantly higher expression than in keratocytes and endothelial cells. Weak expression of DSG1-3 in keratocytes and DSG2 in endothelial cells was observed, although the detection of each was at a level near the detection limit of qPCR.

\section{Altered DSG3 and DSG4 protein expression in PV cornea}

All four DSG proteins were detected in non-diseased donor cornea by F-IHC, demonstrating localization to the borders of the epithelial cells (Figure 5). While DSG1-3 were detected in all the layers of the epithelium, DSG4 was localized to the superficial epithelial cell layers. Although the expression of DSG1 and DSG2 was not significantly altered in PV corneal epithelium compared with non-diseased donor cornea, DSG3 and DSG4 demonstrated a marked alteration in their expression and localization within PV corneal epithelium. In contrast to donor corneal epithelium, DSG3 was primarily localized to the most superficial epithelial cell layers in PV and demonstrated a marked reduction in expression in the remainder of the epithelium.
Compared with donor corneal epithelium, the expression of DSG4 in PV epithelium was diffuse and exclusively localized to the cytoplasm of corneal epithelial cells. While DSG4 was detected in normal donor corneal epithelium (superficial layers), it is reasonable to speculate that the results obtained for the PV epithelium may be an artifact. None of the DSG proteins were detected in the corneal stroma or endothelium (data not shown), consistent with the qPCR results. The corneal epithelium was also positive for the corneal epithelial biomarker KRT12, a component of type I intermediate filaments present in the cytoplasm.

\section{Differential localization of Immunoglobulins G1 and G4 in PV cornea}

To determine the type of anti-DSG3 immunoglobulins potentially mediating the reduction of DSG3 protein in PV corneal epithelium, we performed F-IHC for the two types of $\lg G$ (IgG1 and $\lg G 4$ ) that are most commonly associated with PV (Figure 6). IgG1 and IgG4 were not detected in normal donor corneal epithelium. However, both immunoglobulins were detected in the epithelium and stroma of the PV cornea. In addition, these immunoglobulins were detected as diffuse and/or punctate foci within the anterior stroma, where they were associated with the neovasculature, with IgG4 demonstrating more numerous fluorescent foci. Although both immunoglobulins were detected in the stroma, only IgG4 localized to the cell-cell contacts in the epithelium, mirroring the expression pattern observed for the DSGs, and associated with the marked reduction in DSG3 levels.

\section{Discussion}

Desmogleins are a small group of proteins that are members of the cadherin superfamily, and together with desmocollins are an important component of desmosomes, which are involved in cell adhesion ${ }^{20}$. The corneal expression of the desmogleins has been previously examined, primarily in animal models, with early studies having been mostly restricted to DSG121-28. More recent investigations have described the expression of DSG proteins in human corneal tissue, but have often only investigated the expression of one DSG protein $^{29-33}$. Together these studies have provided evidence of the expression of DSG3 in human corneal epithelium without specific evaluation for DSG1, DSG2, and DSG4 expression ${ }^{29,33}$. We demonstrate that DSG14 are all expressed in the human corneal epithelium, 

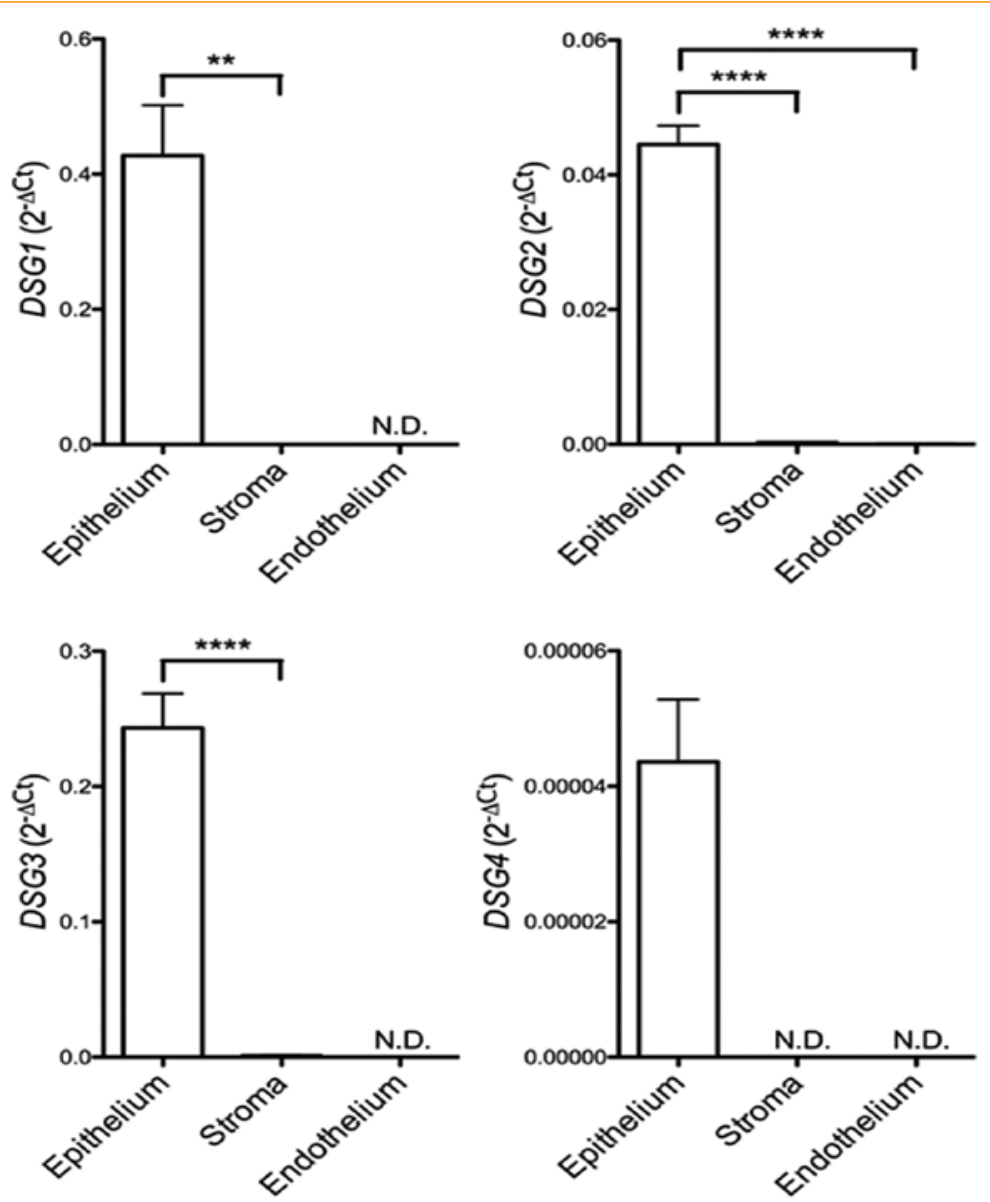

Figure 4. Measurement of corneal DSG transcript levels using qPCR. Transcripts for DSG1-4 were expressed in the epithelium at levels significantly higher than in the stroma and endothelium. Relative expression was plotted as $2^{-\triangle C} T^{\prime}$ with GAPDH transcript used as the reference gene to calculate relative expression. Statistical analysis was performed using the unpaired t-test $(n=4)$.

${ }^{* *} \mathrm{p} \leq 0.01 ;{ }^{* * \mathrm{p}} \mathrm{p} \leq 0.001 ;{ }^{* * * *} \mathrm{p} \leq 0.0001$ (error bars = SEM). N.D. $=$ not detected.

with DSG1-3 present in the majority of the epithelial cell layers and DSG4 expressed only in the superficial epithelial cell layers.

It is well documented in the literature that DSG3 is the primary desmosomal cadherin involved in $\mathrm{PV}^{34}$. The demonstration of markedly reduced DSG3 levels in the corneal epithelium in PV as compared to the normal cornea, as well as the identification of IgG4 autoantibodies in the corneal epithelium, indicate that the corneal involvement in PV is mediated in whole or in part by autoantibodies to DSG3. This is in line with the presence of circulating anti-DSG3 autoantibodies in PV patients ${ }^{35}$.

Some have suggested that the low incidence of ocular findings associated with PV is due to the ability of non-desmoglein proteins to compensate for the loss of DSG3 function caused by anti-DSG autoantibodies in
$\mathrm{PV}^{9}$. Expression of multiple DSG proteins may also decrease the likelihood of developing anti-DSG-mediated corneal pathology, since the non-targeted DSGs are predicted to maintain the integrity of the epithelium and thus compensate for the loss of any single DSG ${ }^{36,37}$. The so called desmoglein compensation theory may explain the exceedingly low incidence of corneal involvement in PV and other anti-DSG-mediated diseases. Although we demonstrate that all four DSG proteins are present in the corneal epithelium, we describe a pronounced corneal phenotype in the case we present. These data suggests that the mechanism resulting in the pathophysiology in the patient we describe is more complex and may include a component that overcomes the presumed protective effect of the expression of multiple DSGs. While the low incidence of corneal findings 


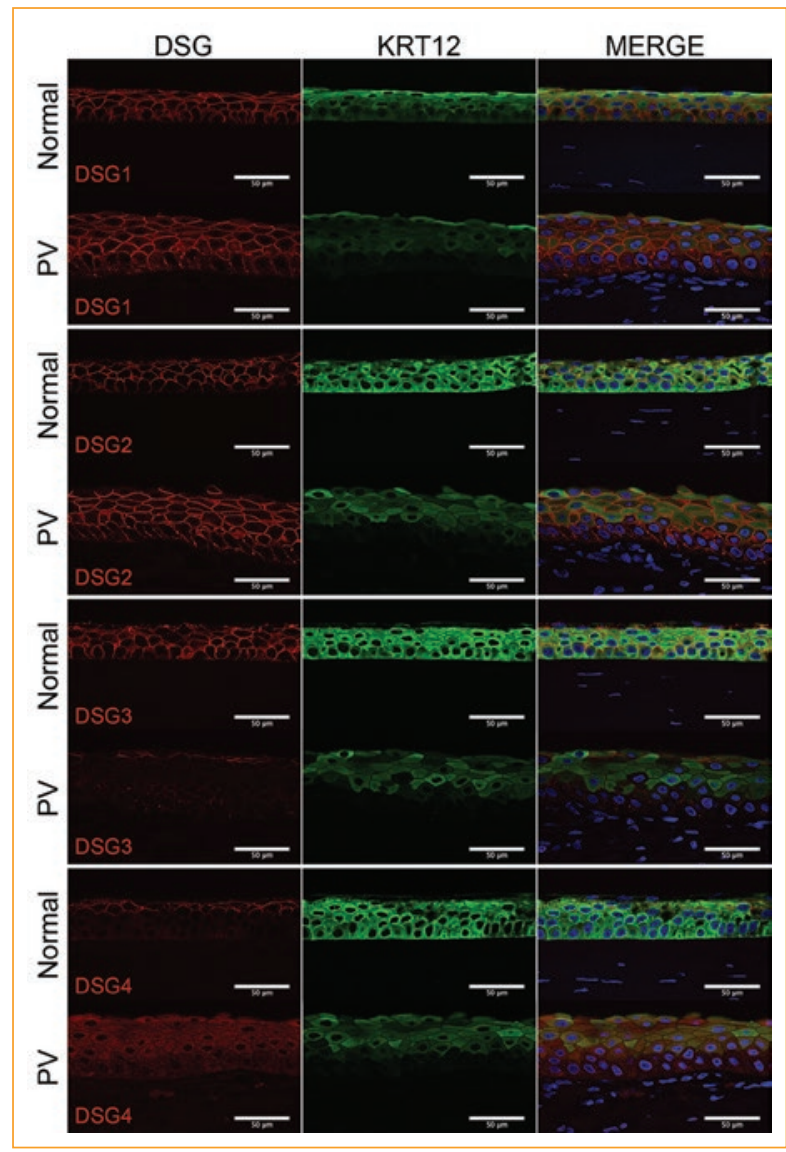

Figure 5. Assessment of DSG1-4 protein expression in donor and PV corneal tissue by fluorescenceimmunohistochemistry. First column: in donor corneal epithelium (Normal), all four DSG proteins (red) were detected at the cell-cell contacts; in corneal epithelium in PV (PV), DSG1 and 2 demonstrated similar expression as control, but the expression of DSG3 and DSG4 were reduced. Second column: the corneal epithelial expression of KRT12 (green), a corneal epithelial specific biomarker, was used as a positive control.

Third column: merged images including DAPI (blue; cell nucleus) counterstain to identify the nuclei.

Scale bar $=50 \mu \mathrm{m}$.

in PV may indirectly support the desmoglein compensation theory, the case we present may present a direct counter to the theory or at least an exception.

A second barrier to corneal involvement is that the cornea is normally avascular, limiting the ability of immune cells and immunoglobins to infiltrate the cornea. The patient we report had chronic red eyes since childhood (based on history), possibly resulting in the corneal neovascularization evident at the time of presentation. The loss of corneal avascularity would allow immunoglobulins to localize to the corneal epithelium and overcome the protective effect of other DSGs that were present.

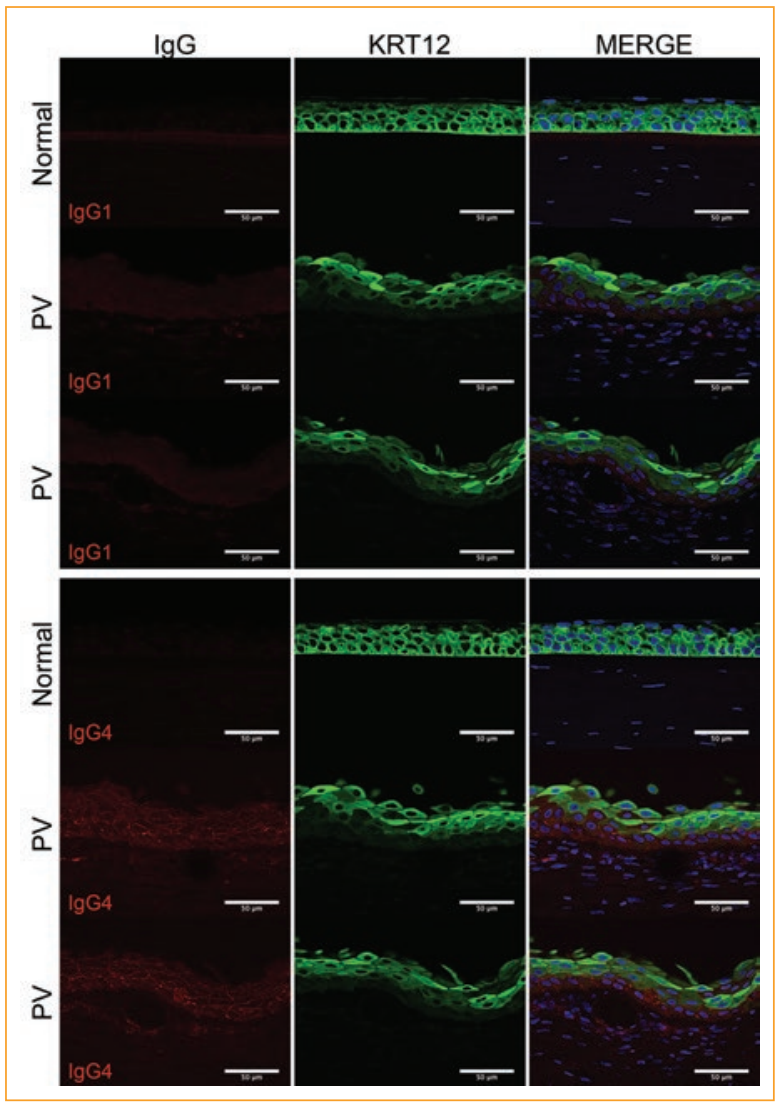

Figure 6. Localization of immunoglobulins $\mathrm{G} 1$ and $\mathrm{G} 4$ in PV cornea was determined by F-IHC. First column: in donor corneal epithelium (Normal), neither IgG1 nor IgG4 (red) was detected; in PV corneal epithelium, IgG1 was not visualized, while IgG4 localized to the cell-cell contacts. Second column: the corneal epithelial expression of KRT12 (green), a corneal epithelial specific biomarker, was used as a positive control.

Third column: merged images including DAPI (blue; cell nucleus) counterstain to identify the nuclei.

Scale bar $=50 \mu \mathrm{m}$.

\section{Conclusions}

Although PV primarily involves the skin and oral mucosa, the corneal epithelium may also be affected. Herein we demonstrated altered corneal epithelial DSG expression in PV and demonstrated localization of IgG4 to the cell-cell contacts in the PV corneal epithelium, providing a pathophysiologic mechanism for these unusual but prominent corneal features. Thus, in the absence of any identifiable secondary cause, corneal pathology associated with PV is most likely mediated by autoantibodies directed against DSG3 in the corneal epithelium. We also demonstrated corneal expression of all four DSG genes and provided a comprehensive overview of DSG expression in the corneal epithelium. 


\section{Ethical disclosures}

Protection of human and animal subjects. The authors declare that the procedures followed were in accordance with the regulations of the relevant clinical research ethics committee and with those of the Code of Ethics of the World Medical Association (Declaration of Helsinki).

Confidentiality of data. The authors declare that they have followed the protocols of their work center on the publication of patient data.

Right to privacy and informed consent. The authors have obtained the written informed consent of the patients or subjects mentioned in the article. The corresponding author is in possession of this document.

\section{Funding}

Support provided by National Eye Institute grants R01 EY022082 (A.J.A.), P30 EY000331 (core grant to Stein Eye Institute) and an unrestricted grant from Research to Prevent Blindness (Stein Eye Institute).

\section{References}

1. Korman N. Pemphigus. J Am Acad Dermatol. 1988;18:1219-1238.

2. Daoud YJ, Cervantes R, Foster CS, et al. Ocular pemphigus. J Am Acad Dermatol. 2005:53:585-590.

3. Laforest C, Huilgol SC, Casson R, et al. Autoimmune bullous diseases: ocular manifestations and management. Drugs. 2005;65:1767-1779.

4. Santoro FA, Stoopler ET, Werth VP. Pemphigus. Dent Clin North Am. 2013;57:597-610.

5. Anan T, Shimizu F, Hatano Y, et al. Paraneoplastic pemphigus associated with corneal perforation and cutaneous alternariosis: a case report and review of cases treated with rituximab. J Dermatol. 2011;38:10841089

6. Joly P, Richard C, Gilbert D, et al. Sensitivity and specificity of clinical, histologic, and immunologic features in the diagnosis of paraneoplastic pemphigus. J Am Acad Dermatol. 2000;43:619-626.

7. Akhyani M, Keshtkar-Jafari A, Chams-Davatchi $C$, et al. Ocular involvement in pemphigus vulgaris. J Dermatol. 2014;41:618-621.

8. Esmaili N, Chams-Davatchi C, Valikhani M, et al. Pemphigus vulgaris in Iran: a clinical study of 140 cases. Int J Dermatol. 2007;46:1166-1170.

9. Olszewska M, Komor M, Mazur M, et al. Response of ocular pemphigus vulgaris to therapy. Case report and review of literature. J Dermatol Case Rep. 2008;2:1-3.

10. Palleschi GM, Giomi B, Fabbri P. Ocular involvement in pemphigus. Am J Ophthalmol. 2007:144:149-152.

11. Hodak E, Kremer I, David M, et al. Conjunctival involvement in pemphigus vulgaris: a clinical, histopathological and immunofluorescence study. $\mathrm{Br} \mathrm{J}$ Dermatol. 1990;123:615-620.

12. Baykal HE, Pleyer U, Sonnichsen K, et al. [Severe eye involvement in pemphigus vulgaris] Ophthalmologe 1995:92:854-857.

13. Lifshitz T, Levy J, Cagnano E, et al. Severe conjunctival and eyelid involvement in pemphigus vulgaris. Int Ophthalmol. 2004;25:73-74.

14. Suami M, Kato M, Koide $\mathrm{K}$, et al. Keratolysis in a patient with pemphigus vulgaris. Br J Ophthalmol. 2001;85:1263-1264.

15. Chirinos-Saldana P, Zuniga-Gonzalez I, Hernandez-Camarena JC, et al. Cicatricial changes in ocular pemphigus. Eye (Lond). 2014;28:459-465.

16. Wang X, Seed B. A PCR primer bank for quantitative gene expression analysis. Nucleic Acids Res. 2003;31:e154.

17. Spandidos A, Wang $\mathrm{X}$, Wang $\mathrm{H}$, et al. A comprehensive collection of experimentally validated primers for Polymerase Chain Reaction quantitation of murine transcript abundance. BMC Genomics. 2008;9:633.

18. Spandidos A, Wang $X$, Wang $H$, et al. PrimerBank: a resource of human and mouse PCR primer pairs for gene expression detection and quantification. Nucleic Acids Res. 2010;38:D792-799.

19. Kim MJ, Frausto RF, Rosenwasser GO, et al. Posterior Amorphous Corneal Dystrophy Is Associated with a Deletion of Small Leucine-rich Proteoglycans on Chromosome 12. PLoS One. 2014:9:e95037.

20. Delva E, Tucker DK, Kowalczyk AP. The desmosome. Cold Spring Harb Perspect Biol. 2009;1:a002543.

21. Rubinstein N, Stanley JR. Pemphigus foliaceus antibodies and a monoclonal antibody to desmoglein I demonstrate stratified squamous epithelial-specific epitopes of desmosomes. Am J Dermatopathol. 1987;9:510-514.

22. Kapprell HP, Owaribe K, Franke WW. Identification of a basic protein of $\mathrm{Mr} 75,000$ as an accessory desmosomal plaque protein in stratified and complex epithelia. J Cell Biol. 1988;106:1679-1691.

23. Suzuki K, Tanaka T, Enoki M, et al. Coordinated reassembly of the basement membrane and junctional proteins during corneal epithelial wound healing. Invest Ophthalmol Vis Sci. 2000;41:2495-2500.

24. Messent AJ, Blissett MJ, Smith GL, et al. Expression of a single pair of desmosomal glycoproteins renders the corneal epithelium unique amongst stratified epithelia. Invest Ophthalmol Vis Sci. 2000;41:8-15.

25. Okada Y, Saika S, Shirai K, et al. Disappearance of desmosomal components in rat corneal epithelium during wound healing. Ophthalmologica. 2001;215:61-65.

26. Davis J, Duncan MK, Robison WG, Jr., et al. Requirement for Pax6 in corneal morphogenesis: a role in adhesion. J Cell Sci. 2003;116:2157-2167.

27. Okada Y, Senba E, Shirai K, et al. Perturbed intraepithelial differentiation of corneal epithelium in c-Fos-null mice. Jpn J Ophthalmol. 2008;52:1-7.

28. Kenchegowda D, Harvey SA, Swamynathan S, et al. Critical role of Klf5 in regulating gene expression during post-eyelid opening maturation of mouse corneas. PLoS One. 2012;7:e44771.

29. Hrdlickova-Cela $\mathrm{E}, \mathrm{Plzak} \mathrm{J}$, Smetana $\mathrm{K}$, Jr. et al Detection of galectin-3 in tear fluid at disease states and immunohistochemical and lectin histochemical analysis in human corneal and conjunctival epithelium. $\mathrm{Br} J$ Ophthalmol. 2001;85:1336-1340.

30. Nielsen K, Heegaard S, Vorum H, et al. Altered expression of CLC, DSG3, EMP3, S100A2, and SLPI in corneal epithelium from keratoconus patients. Cornea. 2005;24:661-668.

31. Yeung AM, Schlotzer-Schrehardt U, Kulkarni B, et al Limbal epithelial crypt: a model for corneal epithelial maintenance and novel limbal regional variations. Arch Ophthalmol. 2008;126:665-669.

32. Gonzalez-Andrades M, Garzon I, Gascon MI, et al. Sequential development of intercellular junctions in bioengineered human corneas. J Tissue Eng Regen Med. 2009;3:442-449.

33. Plzak J, Smetana K, Jr., Hrdlickova E, et al. Expression of galectin-3-reactive ligands in squamous cancer and normal epithelial cells as a marker of differentiation. Int J Oncol. 2001;19:59-64.

34. Koga H, Tsuruta D, Ohyama B, et al. Desmoglein 3, its pathogenecity and a possibility for therapeutic target in pemphigus vulgaris. Expert Opin Ther Targets. 2013:17:293-306.

35. Narbutt J, Boncela J, Smolarczyk K, et al. Pathogenic activity of circulating anti-desmoglein-3 autoantibodies isolated from pemphigus vulgaris patients. Arch Med Sci. 2012;8:347-356.

36. Amagai M. Autoimmunity against desmosomal cadherins in pemphigus. J Dermatol Sci. 1999;20:92-102.

37. Pan M, Liu X, Zheng J. The pathogenic role of autoantibodies in pemphigus vulgaris. Clin Exp Dermatol. 2011;36:703-707. 